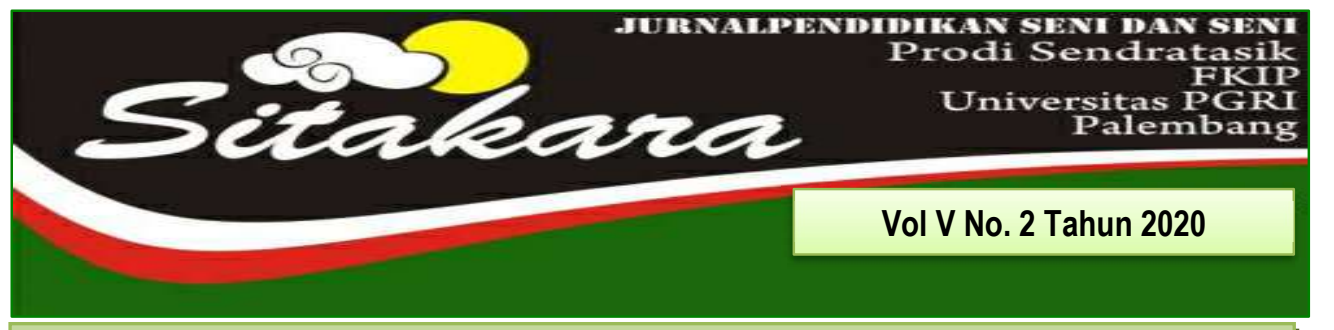

FUNGSI DAN MAKNA BHAJAN PADA UPACARA AGAMA HINDU DI KUIL SHRI MARIAMMAN KOTA MEDAN

(Agung Suharyanto, dkk)

KESENIAN SRANDUL DALAM UPACARA BERSIH DESA BULU KALURAHAN KARANGMOJO KECAMATAN KARANGMOJO KABUPATEN GUNUNGKIDUL YOGYAKARTA

(Supriyanto)

FUNGSI DAN MAKNA LAGU GUBANG DALAM UPACARA SIAR MAMBANG PADA MASYARAKAT TANJUNGBALAI

(Theo henry tua siagian ${ }^{1}$, pulumun p. Ginting ${ }^{2} \&$ wiflihani)

FUNGSI TARI MAPAK ADAT MUARA KUANG SEBAGAI TARI SAMBUT

(Nadia Rahma Aprilia', Dessy Wardiah², Treny Hera ${ }^{3}$ )

MAKNA SIMBOLIK RAGAM HIAS PADA RUMAH LIMAS PALEMBANG

(Ferri Hidayad ${ }^{1}$ Decky Kunian ${ }^{2}$ )

GAYA MUSIK SAHILIN DALAM KESENIAN MUSIK BATANGHARI SEMBILAN DI KOTA PALEMBANG

(Feri Firmansyah)

TRANSPOSISI TTI (TRANSFER, TRANSLATION, IMITATE) DALAM PEMBELAJARAN NOTASI MUSIK MELALUI SCORE CREATOR

(A Heryanto ${ }^{1}$ Dedy Firmansyah ${ }^{2}$ )

RASE TAK SERUPE MUSIK MELAYU TRADISI DENGAN PENGEMBANGAN MUSIK MODERN DALAM RUANG PERTUNJUKAN KOMPOSISI MUSIK NUSANTARA (Rio Eka Putra)

BENTUK SYAIR LAGU DALAM PERTUNJUKAN SYAROFAL ANAM DI PEDESTRIAN S UDIRMAN KOTA PALEMBANG

(Nofroza Yelli ${ }^{1}$ Deria Sepdwiko² ${ }^{2}$

"Betenun" Sebuah Wujud Proses Kreatif Mahasiswa Seni Pertunjukan Universitas PGRI PALEMBANG

(Nurdin $^{1}$ Naomi Diah Budi Setyaningrum ${ }^{2}$ ) 
DAFTAR ISI

FUNGSI DAN MAKNA BHAJAN PADA UPACARA AGAMA HINDU DI KUIL 1-15 SHRI MARIAMMAN KOTA MEDAN

(Agung Suharyanto, dkk)

KESENIAN SRANDUL DALAM UPACARA BERSIH DESA BULU KALURAHAN

$16-26$

KARANGMOJO KECAMATAN KARANGMOJO KABUPATEN GUNUNGKIDUL YOGYAKARTA

(Supriyanto)

FUNGSI DAN MAKNA LAGU GUBANG DALAM UPACARA SIAR MAMBANG 27-39 PADA MASYARAKAT TANJUNGBALAI

(Theo henry tua siagian ${ }^{1}$, pulumun $p$. Ginting ${ }^{2} \&$ wiflihani)

FUNGSI TARI MAPAK ADAT MUARA KUANG SEBAGAI TARI SAMBUT

40-52

(Nadia Rahma Aprilia', Dessy Wardiah², Treny Hera')

MAKNA SIMBOLIK RAGAM HIAS PADA RUMAH LIMAS PALEMBANG

53-61

(Ferri Hidayad ${ }^{1}$ Decky Kunian ${ }^{2}$ )

GAYA MUSIK SAHILIN DALAM KESENIAN MUSIK BATANGHARI SEMBILAN DI $\quad 62-76$ KOTA PALEMBANG

(Feri Firmansyah)

TRANSPOSISI TTI (TRANSFER, TRANSLATION, IMITATE) DALAM 77-85 PEMBELAJARAN NOTASI MUSIK MELALUI SCORE CREATOR (A Heryanto ${ }^{1}$ Dedy Firmansyah ${ }^{2}$ )

RASE TAK SERUPE MUSIK MELAYU TRADISI DENGAN PENGEMBANGAN MUSIK MODERN DALAM RUANG PERTUNJUKAN KOMPOSISI MUSIK NUSANTARA

(Rio Eka Putra)

BENTUK SYAIR LAGU DALAM PERTUNJUKAN SYAROFAL ANAM DI PEDESTRIAN SUDIRMAN KOTA PALEMBANG

(Nofroza Yelli ${ }^{1}$ Deria Sepdwiko ${ }^{2}$ )

"BETENUN" SEBUAH WUJUD PROSES KREATIF MAHASISWA SENI

$109-120$ PERTUNJUKAN UNIVERSITAS PGRI PALEMBANG

(Nurdin ${ }^{1}$ Naomi Diah Budi Setyaningrum ${ }^{2}$ )

86-95 


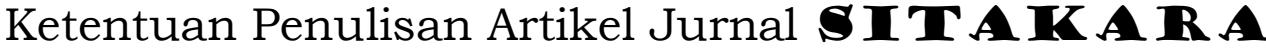

1. Naskah berbahasa Indonesia bertemakan Seni Budaya yang meliputi hasil penelitian pengajaran seni budaya, cabang seni, dan kebudayaan.

2. Naskah harus asli dan belum pernah dimuat dalam media lain. Naskah dapat berupa hasil penelitian perorangan atau kelompok.

3. Naskah ditulis dengan cara-cara yang sesuai dengan ketentuan penulisan artikel ilmiah menggunakan bahasa Indonesia yang baku, berupa ketikan, beserta soft line dalam CD-RW atau dengan mengirimkan email pada redaksi Jurnal SITAKA RA dengan alamat email: jurnalsitakarasendratasik@yahoo.com, spasi 1,5 jenis huruf Arrial Narrow ukuran 12, dengan panjang naskah antara 8-15 halaman pada kertas A4.

4. Artikel hasil penelitian memuat:

JUDUL

Nama Penulis

Abstrak

A. PENDAhuluan

B. METODE PENELITIAN

C. HASIL DAN PEMBAHASAN

D. SIMPULAN

5. Artikel kajian konseptual memuat:

JUDUL

Nama Penulis

Abstrak

PENDAHULUAN
: XXX (HURUF KAPITAL)

: (disertai jabatan dan institusi)

: (Bahasa Indonesia yang memuat 100150 kata diikuti kata kunci, dengan jenis huruf Arrial Narrow dan ukuran huruf 11 spasi tunggal serta dicetak miring)

: (Memuat latar belakang masalah, tinjauan pustaka secara ringkas, masalah penelitian dan tujuan penelitian)

: (Berisi simpulan)

\section{: XXX (HURUF KAPITAL)}

: (disertai jabatan dan institusi)

: (Bahasa Indonesia yang memuat 100150 kata diikuti kata kunci, dengan jenis huruf Arrial Narrow dan ukuran huruf 11 serta dicetak miring)

: (Memuat latar belakang masalah, tinjauan pustaka secara ringkas, 
Sub Judul

Sub Judul

SIMPULAN

DAFTAR PUSTAKA masalah penelitian dan tujuan

penelitian)

: Sesuai dengan kebutuhan (tanpa

numbering)

: (Berisi simpulan dan saran)

: (Berisi pustaka yang dirujuk dalam uraian naskah

6. Referensi sumber dalam teks artikel ditulis dengan menggunakan side note, contoh: (Jalalluddin, 1991:79); (Taufik, 2005;350); (Hamid dan Madjid, 2011:43). Sementara penulisan daftar pustaka disusun dengan ketentuan. Nama Pengarang. Tahun Terbit. Judul (dicetak miring). Kota Terbit: Nama Penerbit. Contoh: Koentjaraningrat. 2010. Manusia dan Kebudayaan Di Indonesia. Jakarta: Djambatan.

Daftar pustaka hanya memuat pustaka/sumber yang dirujuk dalam uraian dan disusun menurut abjad, tanpa nomor urut.

7. Naskah yang dimuat akan disunting kembali oleh redaksi tanpa mengubah isinya.

8. Naskah yang ditolak (tidak bisa dimuat) akan dikirim kembali ke penulis dengan pemberitahuan tertulis dari redaksi atau alamat email.

9. Penulis yang naskahnya dimuat akan mendapatkan 1 (satu) majalah nomor yang bersangkutan.

10. Contact Person: Treny Hera (085357344704) dan Mainur (081373165553). 


\title{
TRANSPOSISI TTI (TRANSFER, TRANSLATION, IMITATE) DALAM PEMBELAJARAN NOTASI MUSIK MELALUI SCORE CREATOR
}

Oleh:

\author{
A Heryanto ${ }^{1}$ Dedy Firmansyah ${ }^{2}$ \\ (FKIP Universitas PGRI Palembang) \\ Email: s1Kesenian@gmail.Com
}

\begin{abstract}
ABSTRAK
Rumusan masalah dalam penelitian ini Bagaimanakah Konsep Transposisi TTI (Transfer, Translation, Imitate) dalam Pembelajaran Notasi Musik melalui Score Creator. Tujuan penelitian ini adalah untuk mengungkap dan mendeskripsikan tentang penerapan Transposisi TTI (Transfer, Translation, Imitate) dalam Pembelajaran Notasi Musik melalui Score Creator. Penelitian ini menggunakan metode kualitatif. Berdasarkan hasil penelitian, Konsep Transposisi TTI (Transfer, Translation, Imitate) dalam Pembelajaran Notasi Musik melalui Score Creator ini dapat efektif dan efisien dengan 6 tahapan: 1) Hal pertama yang perlu guru lakukan adalah menginstruksikan kepada siswa untuk membawa Handphone Android dengan mendownload aplikasi Score Creator pada Google Play Store. 2) Sebelum mengklik menu 'Aplikasi Score Creator' 3) Langkah ke tiga ini adalah tahapan menggunakan aplikasi Score Creator di Handphone siswa masing-masing. 4) Pada tahapan inilah pelatih atau guru dapat mengklarifikasi kepada siswa tentang Notasi sebuah lagu. 5) Langkah berikutnya adalah tahapan "Imitation 6) Langkah terakhir yakni siswa dapat mengulang-ulang memutar "Play" dan (menirukan) bunyi terjemahan Notasi pada aplikasi Score Creator secara mandiri.
\end{abstract}

Kata Kunci : Score Creator,Transposis ( Transfer, Translation, Imitate), Notasi Musik

\section{A. PENDAHULUAN}

Transposisi TTI merupakan

sebuah konsep pembelajaran Notasi

Lagu yaitu proses pemindahan Notasi

Musik ke dalam 3 Ranah: 1)

memindahkan penulisan notasi balok ke dalam aplikasi Score Creator (Transfer

Notasi). 2) Notasi balok dalam aplikasi

Score Creator dipindah atau

diterjemahkan ke dalam bentuk bunyi

(Translation), dan 3) Terjemahan Bunyi
Notasi Balok dalam aplikasi itu dapat langsung berpindah atau ditiru ke dalam suara penyanyi (Imitation). Untuk mempermudah dalam menerapkan sebuah pembelajaran Notasi Lagu dengan Konsep Transposisi TTI (Transfer, Translation, Imitation) ini tentunya diperlukan sebuah media pembelajaran yaitu aplikasi Score Creator. Score Creator adalah aplikasi penulisan notasi lagu, pencipta angka 
dan komposisi musik yang dirancang khusus untuk platform seluler.

Pengguna aplikasi ini sepenuhnya dioptimalkan untuk membuat komposisi musik di perangkat seluler lebih mudah dan lebih cepat dari sebelumnya. Tidak ada lagi "mengetuk dan memperbesar" layar hanya untuk menambahkan catatan musik atau simbol akor. Tidak ada lagi "menyeret dan menjatuhkan" dari palet hanya untuk menambahkan tanda yang tajam / rata. Yang perlu kita lakukan untuk menulis musik hanyalah dengan mengetuk keyboard (catatan dan akor) yang secara harfiah dirancang seperti keyboard teks, yang membantu menulis not musik \& simbol akor dengan mudah. Selain sebagai aplikasi penulisan lagu Score Creator juga berfungsi sebagai alat bantu pengajaran dan pembelajaran musik untuk guru dan siswa. Guru dapat mengajar siswa cara membaca notasi musik dengan langsung menulis catatan musik ke dalam aplikasi dan memutar lagu.

Artinya, Media Score Creator ini tentunya dapat digunakan atau membantu siswa dan guru seni dalam pembelajaran notasi lagu. Secara Praktik, guru dan siswa dapat dengan mudah memindahkan (Transfer) atau menuliskan notasi sebuah lagu ke dalam aplikasi Score Creator. Secara teori guru dan siswa dapat cepat memahami notasi yang ditulis, karena aplikasi Score Creator ini dapat menterjemah (Translation) dan langsung didengar secara benar (dipindah) lewat bunyi. Selain itu, Score Creator ini juga dapat mempermudah guru dan siswa untuk menirukan (Imitate) bunyi notasi lagu yang ditulis ke dalam bentuk suara seseorang.

Menurut peneliti, penggunaan Score Creator ini sangat efektif dan efisien dalam proses pembelajaran notasi sebuah lagu dengan tahapantahapan konsep Transposisi TTI (Transfer, Translation, Imitation).

\section{B. METODE PENELITIAN}

Penelitian ini dilaksanakan dari bulan Februari sampai dengan Akhir Agustus 2020. Balai Pendidikan dan Pelatihan (Diklat) Keagamaan Palembang sebagai salah satu tempat penelitian. Penelitian yang dilakukan di Balai Pendidikan dan Pelatihan (Diklat) Keagamaan Palembang ini tentunya terfokus pada pesertanya yaitu Guru 
Seni Budaya Madrasah Tsanawiyah atau

Madrasah Aliyah sebagai tindaklanjut.

Jenis Penelitian yang peneliti gunakan dalam penggarapan tulisan ini adalah menggunakan Metode Penelitian Kualitatif. Metode Penelitian Kualitatif dipandang peneliti sangat cocok digunakan dalam penelitian ini karena informasi yang didapatkan dari observasi, wawancara dan dokumentasi dapat terkonfirmasi satu sama lainnya (Tringulasi).

C. Hasil Penelitian dan Pembahasan Teknik Penggunaan Aplikasi Score Creator dengan Konsep Transposisi TTI (Transfer Translation - Imitate) dalam Pembelajaran Notasi Musik.

\section{Penggunaan Score Creator}

sangat efektif dan efisien dalam proses pembelajaran notasi sebuah lagu. Dengan Score Creator tentunya penulis atau guru atau pengguna dapat menerapkan konsep Transposisi TTI dalam pembelajaran notasi lagu.
Transposisi TTL merupakan sebuah konsep pembelajaran Notasi Lagu yaitu proses pemindahan Notasi Musik ke dalam 3 Ranah: 1) memindahkan penulisan notasi balok ke dalam aplikasi Score Creator (Transfer Notasi). 2) Notasi balok dalam aplikasi Score Creator dipindah atau diterjemahkan ke dalam bentuk bunyi (Translation), dan 3) Terjemahan Bunyi Notasi Balok dalam aplikasi itu dapat langsung berpindah atau ditiru ke dalam suara penyanyi (Imitation). Untuk lebih detainya akan diperjelas melalui langkah-langkah berikut:

\section{Langkah I}

Hal pertama yang perlu guru lakukan adalah menginstruksikan kepada siswa untuk membawa Handphone Android dengan mendownload aplikasi Score Creator pada Google Play Store. Dan, tak lupa pula guru juga harus menginstruksikan kepada siswa untuk mempersiapkan sebuah lembaran Notasi Musik yang akan dipelajari. Misal: Partitur Notasi Lagu Mengheningkan Cipta, Ciptaan T.Prawit. 

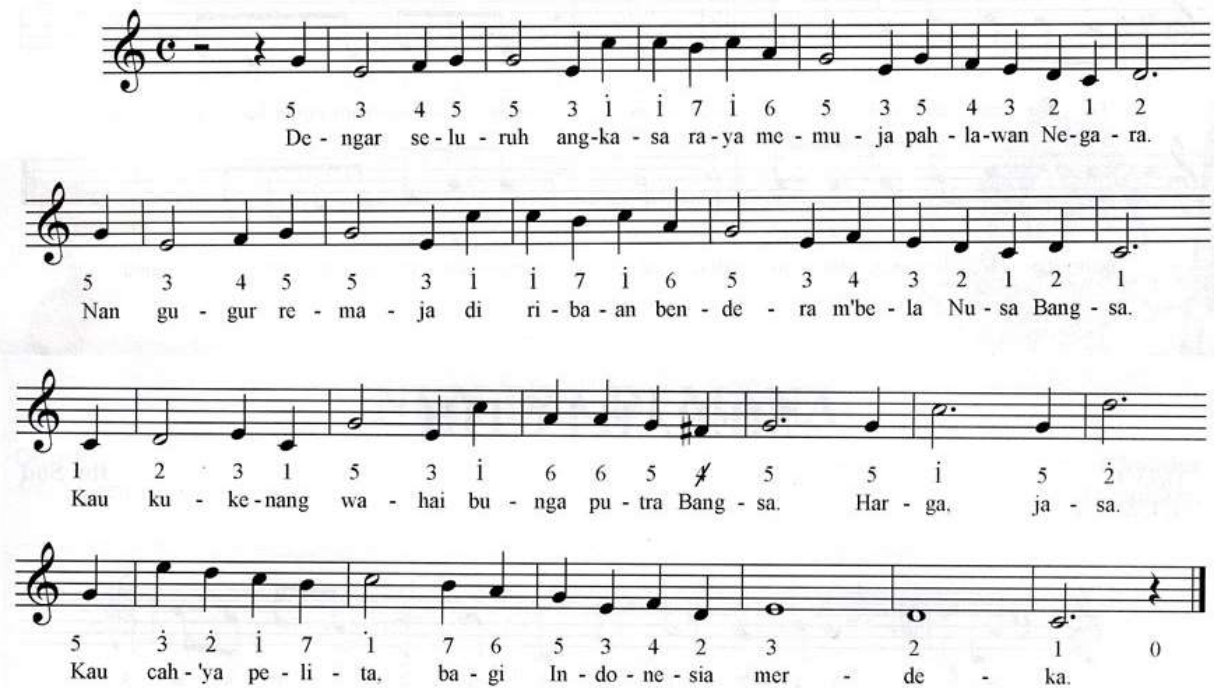

\section{Langkah II}

Sebelum mengklik menu 'Aplikasi Score Creator', dipastikan terlebih dahulu siswa telah memahami hal-hal berikut ini: 1) Bentuk not, 2) Nama not, 3) Nilai-nilai not, 4) fungsi atau letak not di garis paranada, dan sebagainya.

\begin{tabular}{|c|c|c|c|}
\hline Nama Not & Bentuk Not & Tanda Istirahat & Nilai \\
\hline Not Penuh & 0 & & 4 Ketuk \\
\hline Not $1 / 2$ & J & - & 2 Ketuk \\
\hline Not $1 / 4$ & J & & 1 Ketuk \\
\hline Not $1 / 8$ & & $y$ & $1 / 2$ Ketuk \\
\hline Not $1 / 16$ & & $y$ & $1 / 4$ Ketuk \\
\hline Not $1 / 32$ & & $y$ & $1 / 8$ Ketuk \\
\hline
\end{tabular}

\section{Langkah III}

Langkah ke tiga ini adalah tahapan menggunakan aplikasi Score Creator di Handphone siswa masingmasing. Pada tahapan ini guru memandu siswa dalam memindahkan (Transfer) Notasi sebuah lagu yang telah disiapkan, disalin ke dalam aplikasi Score Creator tersebut. Score Creator tentunya memiliki 4 Pilihan Menu yaitu Songs, Setting, Support dan Feedback. Untuk menyalin notasi lagu, guru atau siswa dapat membuka pada menu Songs dan pilih New Song. 

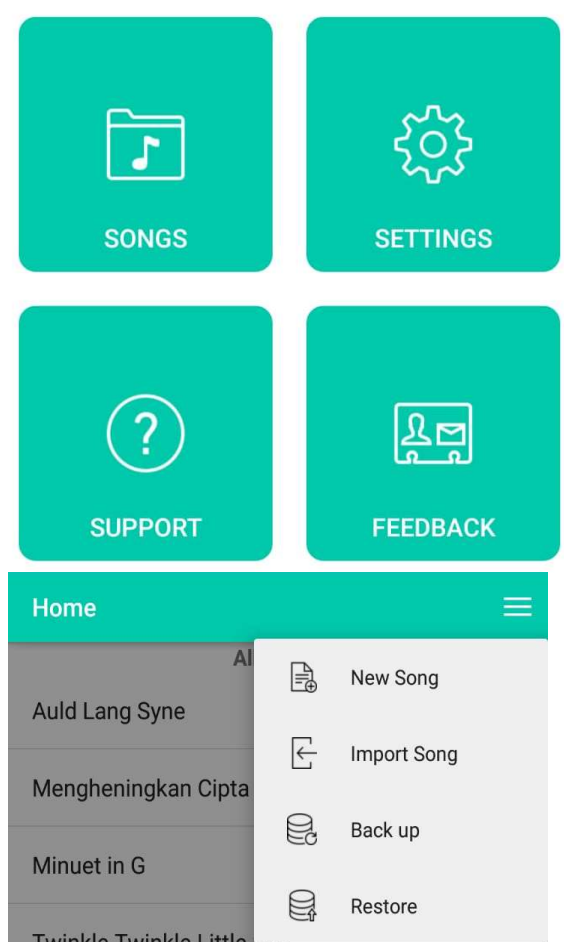

$\equiv$

Twinkle Twinkle Little
Pada menu Song ini siswa dapat memulai dengan mengisi identitas lagu sesuai instruksi guru pada menu New Song yaitu Judul lagu Mengheningkan Cipta, Composer's Note: T.Prawit dengan Tempo 70, Time Signature (Sukat) 4/4, Key Signature (Tone) C Mayor, dan Instrumen pilihannya "Voice". Selanjutnya siswa dapat memulai menyalin (Transfer) satu per satu Notasi lagu mengheningkan Cipta pada aplikasi Score Creator dengan dipandu oleh Instruktur/ guru.
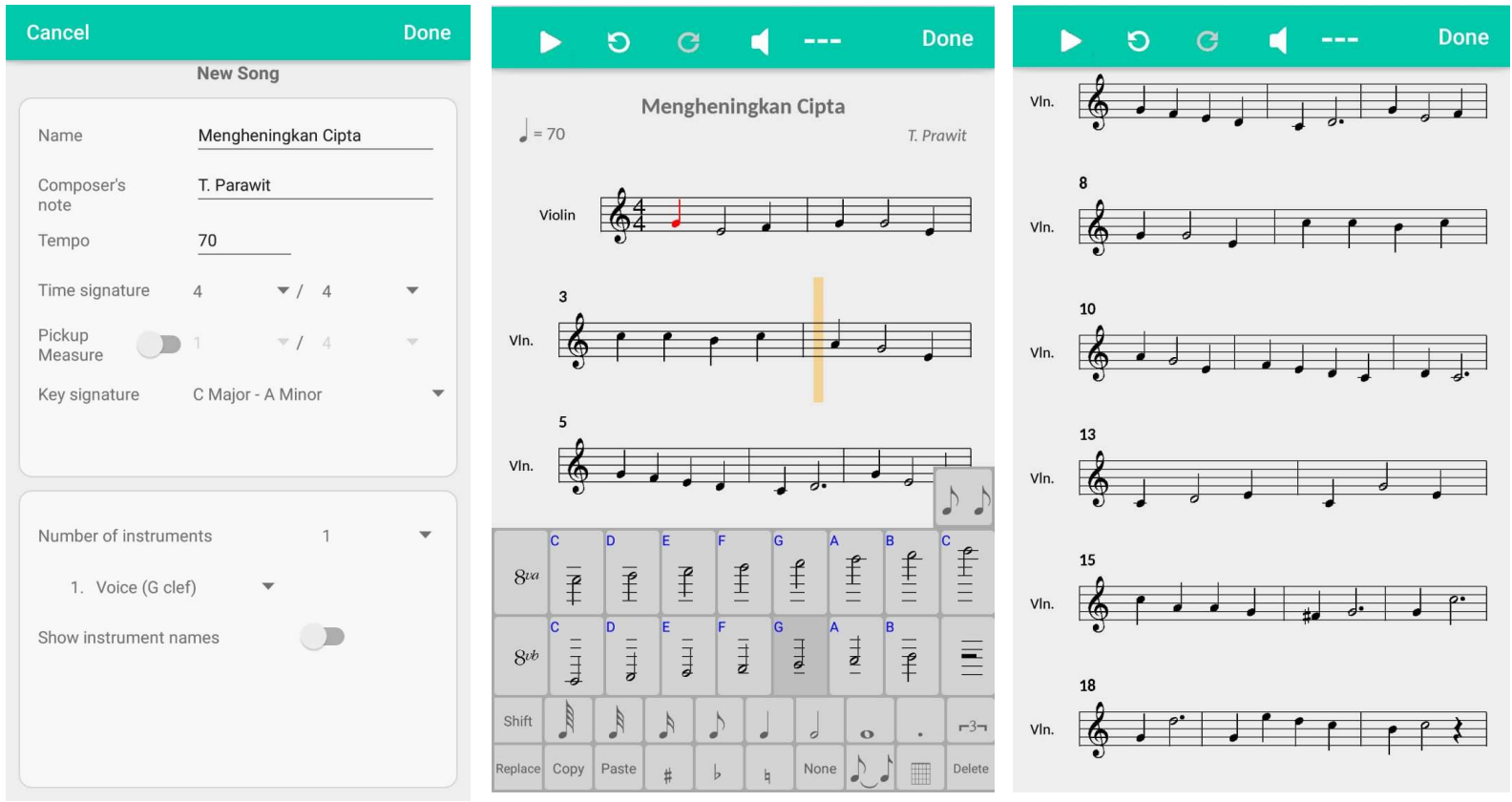


\section{Langkah IV}

Setelah Notasi Lagu tersebut dipindahkan (Transfer) ke aplikasi Score Creator dengan tepat. Pilih menu "Play", dan secara tidak langsung Score Creator dapat menterjemah (Translation) Notasi Lagu tersebut berpindah ke dalam Bunyi. Pada tahapan inilah pelatih atau guru dapat mengklarifikasi kepada siswa tentang Notasi sebuah lagu. Sehingga siswa dapat lebih mudah memahami atau menerjemahkan dari simbol bentuk not, nama not, nilai-nilai not, dan fungsi atau arti dari letak not di garis paranada pada Notasi sebuah lagu. Misalkan contoh pada Gambar dibawah ini terdapat dua (2) perbedaan,. Instruksi diminta memilih Voice (Vokal), kekeliruan dipilih Violin. Guru dapat langsung mengklarifikasi kesalahan siswa dalam menuliskan atau kekeliruan menirukan (transfer) Notasi yang telah ditentukan.

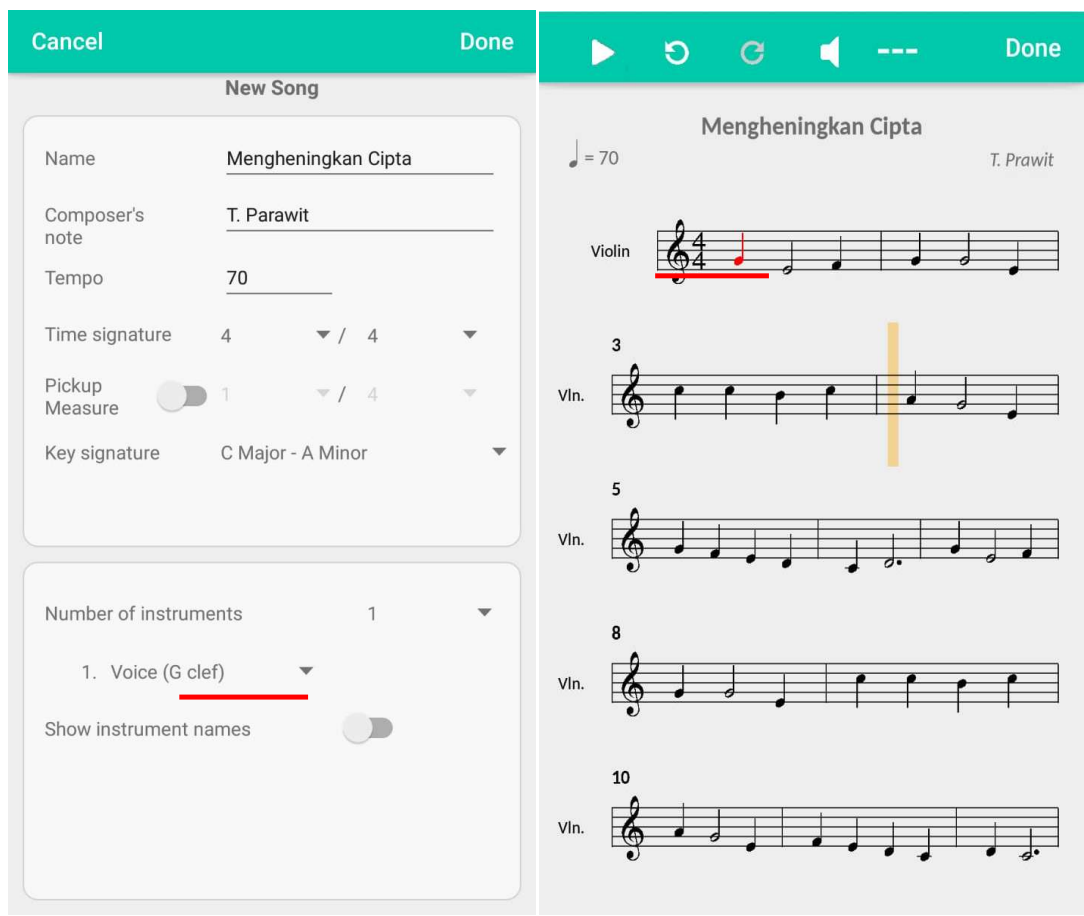

\section{Langkah V}

mengajarkan siswa untuk bernyanyi

Langkah berikutnya adalah dengan mengikuti (menirukan) bunyi tahapan "Imitation". Pada tahapan ini pada aplikasi Score Creator pada pelatih atau guru dapat mengajak dan 
masing-masing Smartphone atau Handphone siswa dengan mengklik Play
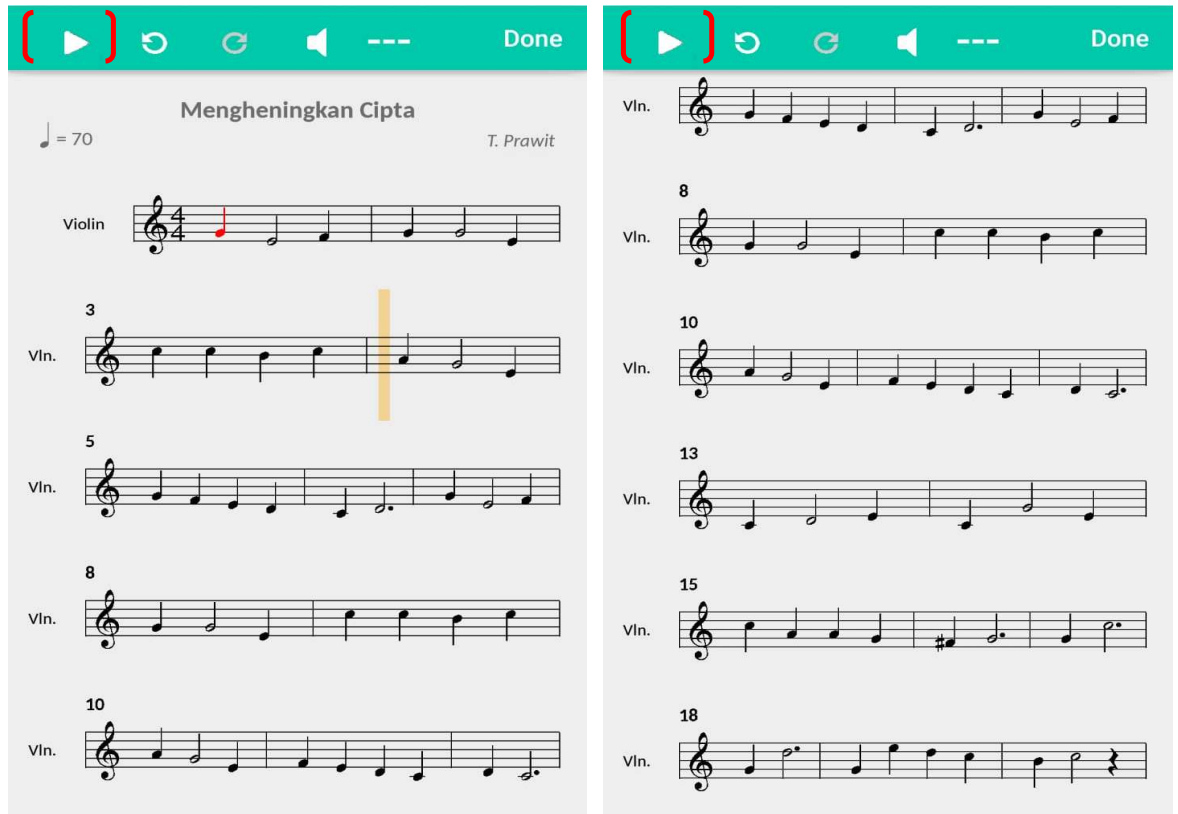

\section{Langkah VI}

(Dokumentasi Nugroho)

Langkah terakhir yakni siswa dapat mengulang-ulang memutar "Play" dan (menirukan) bunyi terjemahan Notasi pada aplikasi Score Creator secara mandiri, sampai siswa benar-benar memahami dan menyanyikan Notasi lagu dengan tepat.

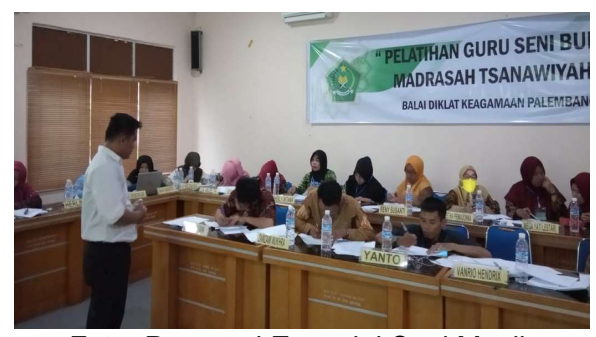

Foto. Pemateri Esensial Seni Musik Pendidikan dan Pelatihan Guru Seni Budaya "Madrasah Tsanawiyah" Balai Diklat Keagamaan se-Sumatera Bagian Selatan
Hasil dari penggunaan aplikasi Score Creator dengan konsep Transposisi TTI (Transfer - Translation Imitate) pada pembelajaran notasi musik ini tentunya dianalisis berdasarkan kebutuhan untuk simpulan atau formulasi atau rumusan konsep baru tentang pembelajaran notasi musik dengan mudah dan tepat. Berdasarkan hasil penelitian, penulis (sekaligus pemateri) pada Pendidikan dan Pelatihan Guru Seni Budaya "Madrasah Tsanawiyah" atau "Madrasah Aliyah" Balai Diklat Keagamaan se-Sumatera Bagian 
Selatan pada tahun 2020 ini secara mayoritas pesertanya menyatakan bahwa pengaplikasian Score Creator dengan Konsep Transposisi TTI (Transfer, Translation, Imitate) ini sangat efisien dan efektif untuk pembelajaran Notasi Balok dan sekaligus pembelajaran Vokal (Menyanyi).

\section{SIMPULAN}

Konsep Transposisi TTI

(Transfer, Translation, Imitate) dalam Pembelajaran Notasi Musik melalui Score Creator ini dapat efektif dan efisien dengan 6 tahapan: 1) Hal pertama yang perlu guru lakukan adalah menginstruksikan kepada siswa untuk membawa Handphone Android dengan mendownload aplikasi Score Creator pada Google Play Store. Dan, tak lupa pula guru juga harus menginstruksikan kepada siswa untuk mempersiapkan sebuah lembaran Notasi Musik yang akan dipelajari. Misal: Partitur Notasi Lagu Mengheningkan Cipta, Ciptaan T.Prawit. 2) Sebelum mengklik menu 'Aplikasi Score Creator', dipastikan terlebih dahulu siswa telah memahami hal-hal berikut ini: a) Bentuk not, b) Nama not, c) Nilai-nilai not, d) fungsi atau letak not di garis paranada, dan sebagainya. 3) Langkah ke tiga ini adalah tahapan menggunakan aplikasi Score Creator di Handphone siswa masing-masing. Pada tahapan ini guru memandu siswa dalam memindahkan (Transfer) Notasi sebuah lagu yang telah disiapkan, disalin ke dalam aplikasi Score Creator tersebut. Score Creator tentunya memiliki 4 Pilihan Menu yaitu Songs, Setting, Support dan Feedback. Untuk menyalin notasi lagu, guru atau siswa dapat membuka pada menu Songs dan pilih New Song. Pada menu Song ini siswa dapat memulai dengan mengisi identitas lagu sesuai instruksi guru pada menu New Song yaitu Judul lagu Mengheningkan Cipta, Composer's Note: T.Prawit dengan Tempo 70, Time Signature (Sukat) 4/4, Key Signature (Tone) C Mayor, dan Instrumen pilihannya "Voice". Selanjutnya siswa dapat memulai menyalin (Transfer) satu per satu Notasi lagu mengheningkan Cipta pada aplikasi Score Creator dengan dipandu oleh Instruktur/ pelatih/ guru. 4) Setelah Notasi Lagu tersebut dipindahkan (Transfer) ke aplikasi Score Creator dengan tepat. Pilih menu "Play", dan secara tidak langsung Score Creator dapat menterjemah (Translation) Notasi Lagu tersebut berpindah ke dalam 
Bunyi. Pada tahapan inilah pelatih atau guru dapat mengklarifikasi kepada siswa tentang Notasi sebuah lagu. Sehingga siswa dapat lebih mudah memahami atau menerjemahkan dari simbol bentuk not, nama not, nilai-nilai not, dan fungsi atau arti dari letak not di garis paranada pada Notasi sebuah lagu. Artinya, Guru dapat langsung mengklarifikasi kesalahan siswa dalam menuliskan atau kekeliruan menirukan (transfer) Notasi yang telah ditentukan. 5) Langkah berikutnya adalah tahapan "Imitation".
Pada tahapan ini pelatih atau guru dapat mengajak dan mengajarkan siswa untuk bernyanyi dengan mengikuti (menirukan) bunyi pada aplikasi Score Creator pada masing-masing Smartphone atau Handphone siswa yaitu dengan mengklik Play. 6) Langkah terakhir yakni siswa dapat mengulang-ulang memutar "Play" dan (menirukan) bunyi terjemahan Notasi pada aplikasi Score Creator secara mandiri, sampai siswa benar-benar memahami dan menyanyikan Notasi lagu dengan tepat.

\section{DAFTAR PUSTAKA}

https://play.google.com/store/apps/details?id=com.sc.scorecreator\&hl=en). Diakses pada tanggal 10 Agustus 2019. 